University of Nebraska - Lincoln

DigitalCommons@University of Nebraska - Lincoln

2009

\title{
A multiple species approach to biomass production from native herbaceous perennial feedstocks
}

\author{
J. L. Gonzalez-Hernandez \\ South Dakota State University
}

Gautam Sarath

United States Department of Agriculture -Agricultural Research Service, Gautam.sarath@ars.usda.gov

J. M. Stein

South Dakota State University

V. Owens

South Dakota State University

K. Gedye

South Dakota State University

See next page for additional authors

Follow this and additional works at: https://digitalcommons.unl.edu/biochemistrysarath

Part of the Biochemistry, Biophysics, and Structural Biology Commons

Gonzalez-Hernandez, J. L.; Sarath, Gautam; Stein, J. M.; Owens, V.; Gedye, K.; and Boe, A., "A multiple species approach to biomass production from native herbaceous perennial feedstocks" (2009). Gautam Sarath Publications. 13.

https://digitalcommons.unl.edu/biochemistrysarath/13

This Article is brought to you for free and open access by the Biochemistry, Department of at DigitalCommons@University of Nebraska - Lincoln. It has been accepted for inclusion in Gautam Sarath Publications by an authorized administrator of DigitalCommons@University of Nebraska - Lincoln. 


\section{Authors}

J. L. Gonzalez-Hernandez, Gautam Sarath, J. M. Stein, V. Owens, K. Gedye, and A. Boe 


\title{
A multiple species approach to biomass production from native herbaceous perennial feedstocks
}

\author{
J. L. Gonzalez-Hernandez • G. Sarath • J. M. Stein • \\ V. Owens $\cdot$ K. Gedye $\cdot$ A. Boe
}

Received: 18 February 2009 / Accepted: 20 April 2009 /Published online: 28 May 2009 / Editors: P. Lakshmanan; D. Songstad

(C) The Society for In Vitro Biology 2009

\begin{abstract}
Due to the rapid rate of worldwide consumption of nonrenewable fossil fuels, production of biofuels from cellulosic sources is receiving increased research emphasis. Here, we review the feasibility to produce lignocellulosic biomass on marginal lands that are not well-suited for conventional crop production. Large areas of these marginal lands are located in the central prairies of North America once dominated by tallgrass species. In this article, we review the existing literature, current work, and potential of two native species of the tallgrass prairie, prairie cordgrass (Spartina pectinata), and little bluestem (Schizachyrium scoparium) as candidates for commercial production of biofuel. Based on the existing literature, we discuss the need to accelerate research in the areas of agronomy, breeding, genetics, and potential pathogens. Cropping systems based on maintaining biodiversity across landscapes are essential for a sustainable production and to mitigate impact of pathogens and pests.
\end{abstract}

Keywords Biomass $\cdot$ Herbaceous perennial feedstocks . Marginal lands $\cdot$ Little bluestem $\cdot$ Prairie cordgrass

\section{Introduction}

This review evaluates the rationale for using a variety of native perennial herbaceous species for the emerging

\footnotetext{
J. L. Gonzalez-Hernandez $(\bowtie) \cdot J$. M. Stein $\cdot$ V. Owens

K. Gedye $\cdot$ A. Boe

Department of Plant Sciences, South Dakota State University, Brookings, SD 57007, USA

e-mail: jose.gonzalez@sdstate.edu

G. Sarath

Grain, Forage and Bioenergy research Unit, USDA-ARS, Lincoln, NE, USA
}

lignocellulosic fuel sector and considers potential biotic threats that could impact this venture. Recent and previous reviews on herbaceous feedstocks have had a distinctly switchgrass flavor, as this crop (Panicum virgatum L.) had emerged as a lead perennial herbaceous candidate from a large body of study that was funded by the US-Department of Energy (Bouton 2007; McLaughlin and Kszos 2005; Parrish and Fike 2005; Sarath et al. 2008; Vogel et al. 2002). As a result of this interest, several important strides have been made in the development of genomic and other resources for switchgrass (Bouton 2007; Martinez-Reyna and Vogel 2008; Missaoui et al. 2005; Mitchell et al. 2002; Tobias et al. 2005, 2006, 2008). In addition, recent studies have demonstrated that switchgrass can be effectively transformed to produce polyhydroxybutyrate (Somleva et al. 2008), potentially opening the way for future engineering of quality parameters in this species. Taken together, these studies of switchgrass have provided a robust framework to evaluate other potential herbaceous perennial feedstocks and point out the detailed agronomic, genomic, breeding, and management infrastructures that will have to be developed for each species.

Vogel and Jung (2001) have made a number of research recommendations for developing herbaceous bioenergy crops. These recommendations centered on the need for efficient and rapid analyses of biomass quality and the need for greater understanding of the genetics and linkage parameters affecting traits of interest in these species. However, underlying assumptions included that these perennial crops would be grown on marginal land, could be cost effectively harvested, stored, and converted into a liquid fuel such as ethanol. Although conversion of biomass into liquid fuels, especially ethanol, has received significant interest and funding (Cardona and Sanchez 2007; Chen and Dixon 2007; Dien et al. 2006; Schmer et al. 2008; Simpson 
et al. 2008), several alternate platforms exist for converting biomass into energy including the production of syngas, pyrolysis oils, and through burning in coal-fired power plants (Demirbas 2008; Gaunt and Lehmann 2008; Keshwani and Cheng 2009). In each of these cases, biomass quality parameters can be important. As an example, low lignin biomass is probably most suitable in an ethanol biorefinery (Chen and Dixon 2007; Sarath et al. 2008) whereas biomass with higher levels of aromatics would possess greater energy content and potentially be a better fit for direct-conversion strategies. Thus, to a certain extent, ideal biomass quality will be driven by the conversion platform it is ultimately intended for, although all herbaceous species raised for bioenergy purposes (at least in the continental USA) will share several common traits.

First, an herbaceous bioenergy crop should not compete directly with food crops for land or other resources. Second, it must have fairly broad environmental adaptation with sustainable yields while requiring limited inputs. Third, it must be a perennial with good regrowth potential and tolerance to both biotic and abiotic stresses. Finally, it must be amenable for improvement through traditional, molecular, or/and engineered breeding. Given the edaphic and environmental variations in the continental USA, no one crop will exhibit all of these attributes across all growing regions, indicating the need to evaluate and develop multiple species with good adaptation to specific climatic and edaphic zones. These considerations suggest that native plants that have evolved within a specific plant adaptation region would be good targets for improvement (Tobias et al. 2005). Finally, it may be possible to use a mix of native species to create low-input high diversity (LIHD) bioenergy landscapes (Tilman et al. 2006).

Selecting the appropriate native species does present some challenges. Even after a specific species is selected, it will require several years of yield trials across different environments to adequately document its utility as a bioenergy crop. These initial agronomic studies are critical to the future success in deploying herbaceous crops and requires the needed commitment in fiscal, land, and human resources. Among the key factors during initial evaluation of a species is its ability to thrive and produce on marginal land. For our purposes, marginal land is assumed to be farmable, but would not normally support the economic production of food crops. Most of these lands are expected to be classified within the Conservation Reserve Program (CRP) of the USDA.

The question of marginal lands is an important one and requires some discussion. Over the course of the last few years, many studies have raised the food versus fuel debate (Cassman and Liska 2007; Gomez et al. 2008) as well as a range of potential environmental aspects of cultivating dedicated bioenergy crops (Fargione et al. 2008; Schmer et al. 2008; Schnoor 2006; Searchinger et al. 2008). Marginal lands in most producers' fields are attractive for bioenergy purposes since they normally adjoin cropped land and present an added opportunity for producers to obtain value. Placing such land in perennial plants can be expected to maintain most of conservation benefits, such as lowered soil erosion, enhanced soil C-sequestration, minimizing run-off, and providing wildlife habitat and yielding biomass for biorefineries, while allowing producers to get revenue. If the right crop or blend of crops (Schmer et al. 2008; Tilman et al. 2006) are selected, it should be possible to realize both environmental and fuel requirements. There is also the potential to manage noncrop marginal lands for bioenergy uses. An example would be soils and/or environment that favor the growth of a particular native perennial that could be used as a source of lignocellulosic biomass. In fact, part of the current push for herbaceous perennials as a fuel source has its origins from the abundant native tallgrass prairies of the USA.

Prior to the arrival of European immigrants, large tracts of the US Midwest had been under perennial vegetation, dominated by herbaceous grasses comprising both the native tall and short grass prairies. These ecosystems were generally characterized by deep soils containing abundant amounts of soil carbon and enough biomass production to support vast herds of bison and other large herbivores. These rich soils have since provided much of the US cereal grains and other crops, most notably soybeans, maize, and wheat. However, continued annual cropping has led to numerous problems associated with modern agriculture, including soil loss from wind and water erosion, leading to reduced yields and/or loss of arable acres. In addition to the significant resources which have been allocated to deal with these environmental issues, it has become apparent that we could also return to the tallgrass native prairie model to generate biomass for biofuels.

As mentioned earlier, the first plant selected for bioenergy use has been switchgrass. Although switchgrass is not the dominant species in tallgrass prairies, it possesses many useful agronomic traits such as ease of seed harvest, cleaning, and planting. In contrast, the two other more dominant tallgrass prairie species, big bluestem (Andropogon gerardii Vitman) and Indian grass (Sorghastrum nutans (L.) Nash; both chaffy-seeded species), have not received the same level of research interest, although they have yield potentials possibly greater than switchgrass. Similarly, a number of other warm- and cool-season grasses have good potential to yield biomass under specific environmental conditions. These include prairie cordgrass (Spartina pectinata Bosc ex Link), reed canary grass (Phalaris arundinacea L.), bermuda grass (Cyanodon dactylon L.), napiergrass (Pennisetum purpureum Schumach), and the giant reed (Arundo donax L.; Anderson et al. 2008; Dien et al. 2006). Research on 
several of these species is needed in addition to the development of switchgrass as a primary model and possibly the first-generation dedicated bioenergy species.

Numerous studies have touted introduced species with good potential as a bioenergy feedstock. The most dominant of these species has been Miscanthus (Miscanthus $x$ giganteus). Miscanthus appears to possess many of the traits critical for success as a bioenergy feedstock (Christian et al. 2008; Heaton et al. 2004, 2008). It currently suffers from a major limitation; it is a sterile hybrid which requires transplantation of rhizomes. It is possible that this limitation might be overcome through research and agronomic adaptation of transplanting machinery; however, another significant concern is that Miscanthus is a nonnative perennial with broad environmental adaptation. Therefore, it carries some risk of becoming an invasive weed like other such perennial species (Barney and Ditomaso 2008). Although this is not a focus of this review, it should be borne in mind that most of the cultivated crops are exotic introductions and have not posed a major environmental threat when managed appropriately. Given the significant resources that have been committed to the development of Miscanthus (for example http://miscanthus.illinois.edu/), this plant will likely become a member of the herbaceous bioenergy suite of plants.

Based on the switchgrass model, several promising plants need development of genetic, physiological, agronomic, and conversion resources. The development of such resources will allow successful cross-pollination of ideas and lead to discovery of common and species-specific mechanisms that can be deployed for continued improvement of herbaceous feedstocks for bioenergy purposes.

\section{The Tallgrass Prairie of North America: A Model Biomass Production System}

A number of herbaceous perennial feedstocks have been evaluated for their potential to provide high quality lignocellulose to biorefineries of the future. Much of the work has been conducted on switchgrass ( $P$. virgatum L.), a tall-growing, $\mathrm{C}_{4}$ species, native to much of the eastern USA (Hitchcock 1935). In 1991, switchgrass was selected by the US Department of Energy (DOE) as a "model" herbaceous feedstock because it is (1) widely adapted, (2) perennial, (3) grows well on land not highly suited to row crop production, (4) established from seed, and (5) beneficial for soil conservation and wildlife habitat (McLaughlin and Kszos 2005; Parrish and Fike 2005; Sanderson et al. 2006). The benefits of switchgrass are also found in a number of other species of the tallgrass prairie, including prairie cordgrass (S. pectinata Link.; Boe and Lee 2007; Potter et al. 1995), big bluestem (A. gerardii Vitman; Mulkey et al. 2008), M. x giganteus (Heaton et al. 2008), and reed canarygrass ( $P$. arundinacea L.; Sanderson and Adler 2008). Because multiple species are of potential use as feedstocks, knowledge of local environmental conditions, potential limitations due to biotic and abiotic stresses, and other pertinent factors should also play a role in the choice of species for each region.

Tillman et al. (2006) suggested the use of LIHD mixtures of native grasses. They found that LIHD mixtures produced more potential energy on agriculturally degraded and nitrogen-poor sandy soil with no inputs than any of the individual species grown alone. However, biomass production of the LIHD mixture (about $4 \mathrm{Mg} \mathrm{ha}^{-1}$ ) averaged well below the DOE goal of $22 \mathrm{Mg} \mathrm{ha}^{-1}$ (U.S. DOE 2006). In on-farm trials in the Great Plains, USA, switchgrass produced $540 \%$ more renewable than nonrenewable energy consumed (Schmer et al. 2008). In addition, switchgrass managed for high yield produced $93 \%$ more biomass than estimates from the human-made prairie established by Tilman et al. (2006). Switchgrass was a key component in maintaining yields above $5 \mathrm{Mg} \mathrm{ha}^{-1}$ at three locations in the northern Great Plains, USA (Owens et al. 2009, unpublished data). In their trial, switchgrass, big bluestem, and indiangrass were grown in monocultures and all two- and three-way mixtures. These were highly diverse mixes, but one used three of the dominant warm-season grasses of the tallgrass prairie. While switchgrass helped maintain yields, the inclusion of big bluestem improved soil cover.

Russelle et al. (2007) refuted some of the claims made by Tilman et al. (2006), noting that (1) minerals may have been replaced in the system since most biomass was burned after removing small areas within the plots, (2) the establishment difficulties associated with many native prairie species were ignored, (3) the experiment was conducted at only one location and yet results were extrapolated to the entire planet, and (4) the use of corn stover, as well as the grain, would improve the net energy of corn. On the other hand, annual fire events on the Konza Prairie in eastern Kansas, USA increased aboveground net primary productivity (ANPP) of native grasses 8 of $12 \mathrm{yr}$ while ANPP for forbs increased only 4 of $12 \mathrm{yr}$ (Knapp et al. 1998). Precipitation was a key component in increased in ANPP, i.e., in years with adequate precipitation, ANPP was much more likely to increase with burning. It is apparent from these examples that a diversity of species and management approaches will be needed to meet the needs of biorefineries. The decision to grow a monoculture or a mixture of several species will largely be determined by the requirements of the feedstock "consumer" (e.g., cellulosic ethanol facilities), local environmental conditions, types of government subsidies, as well as how society begins to value such diversity.

Many proponents of lignocellulosic biomass note the capability to produce feedstocks on marginal lands. In the 
USA, land capability classes were developed to help technical managers describe soils and their suitability for cultivation (Hockensmith and Steele 1950). Essentially, soils are given a class rating from I to VIII with possible subclasses describing specific limitations within each class. Land capability classes I-IV are suitable for cultivation with varying limitations. Land capability classes V-VIII are unsuitable for cultivation due to characteristics such as flooding, slope, stones, and roughness. However, they may be suitable for grazing or forestry. Because of this, proponents of perennial biomass crops suggest that these species be grown on land rated unsuitable for cultivation (V-VIII), noting that this will help mitigate the food-fuel debate. On the other hand, some authors have noted that conversion of marginal lands to biomass production may have a negative impact on forage-livestock production as pastureland and hayland are pushed to even more marginal lands (Ceotto 2008; Sanderson and Adler 2008). Nonetheless, the focus of this review is on perennial species adapted to marginal land such as those in land capability classes IIIV for which moisture or erosion are the primary limitations to cultivation, land capability class $\mathrm{V}$ on which flooding may frequently occur, and land capability classes VI-VIII where cultivation is not possible (Doolittle et al. 2002).

Class V soils may be affected by salinity or exhibit other problems associated with inherent wetness. There is approximately 13.2 million-hectare class $\mathrm{V}$ land within the contiguous states of the USA (USDA-NRCS 2000). A number of species native to the tallgrass prairie, such as big bluestem, little bluestem (Schizachyrium scoparium [Michx.] Nash), and prairie cordgrass are well-adapted to some or most of the conditions of class V land. Studies using these and other species have been conducted to evaluate their performance on purported marginal land including native, warm-season grass mixtures composed of switchgrass, big bluestem, and indiangrass (S. nutans [L] Nash; Mulkey et al. 2008); switchgrass on land enrolled in the CRP (Mulkey et al. 2006), on reclaimed land (Al-Kaisi and Grote 2007), on multiple farms in the Great Plains (Schmer et al. 2008), and on dryland in eastern Nebraska, USA (Varvel et al. 2008); prairie cordgrass (Boe and Lee 2007); tall fescue (Festuca arundinacea Schreb.) (Wells et al. 2003); and a number of monoculture cool- and warmseason grasses and legumes on reclaimed mine land in Virginia, USA (Evanylo et al. 2005). While the cited work was done on marginal land, it is not clear whether or not it was done on class $\mathrm{V}$ land.

More research is needed on class $\mathrm{V}$ land to ascertain yield, persistence, and management practices to optimize performance of specific species adapted to this environment. By the final years of a 4-yr study, Boe and Lee (2007) reported that two prairie cordgrass populations averaged $9.3 \mathrm{Mg} \mathrm{ha}^{-1}$ compared to $2.0 \mathrm{Mg} \mathrm{ha}^{-1}$ for
"Cave-in-Rock" switchgrass and 4.8 $\mathrm{Mg} \mathrm{ha}^{-1}$ for "Summer" and "Sunburst" switchgrass. In a 10-yr multilocation trial in the upper Great Plains, USA (Tober et al. 2008) reported big bluestem yields from 0.1 to $8.8 \mathrm{Mg} \mathrm{ha}^{-1}$ depending on years and location. However, nitrogen fertilizer was not applied in either of the aforementioned multiyear studies. Mulkey et al. (2008) found that yields of mixtures containing big bluestem, indiangrass, and switchgrass responded some years to $\mathrm{N}$ rates up to $112 \mathrm{~kg} \mathrm{ha}^{-1}$, but addition of $\mathrm{N}$ also increased the percentage of weedy species in the mix.

Basic management information (e.g., establishment, fertilizer practices, harvest timing, harvest methods) is severely lacking for species such as prairie cordgrass and little bluestem, two species adapted to the type of marginal land described in this review. This is particularly true when these species are considered for biomass energy. General guidelines regarding warm-season grass establishment (Masters et al. 2004) and management for biomass (Sanderson et al. 2004) can be found in the literature. However, specific production practices and effects of pests such as weeds, insects, and diseases at diverse environments are severely lacking for all potential feedstock species and especially for the less-studied species like prairie cordgrass, little bluestem, and big bluestem.

\section{Breeding North America Prairies Native Species: Little Bluestem and Prairie Cordgrass}

Little bluestem. Little bluestem [S. scoparium (Michx.) Nash] was the most important dominant of uplands in the central area of the tallgrass prairie. On drier soils, it comprised $50 \%$ to $90 \%$ of the vegetation (Weaver and Fitzpatrick 1932). It was also the dominant species on shallow slopes of the northern region of the tallgrass prairie that extended from southern Manitoba through the eastern Dakotas and western Minnesota. Weaver (1960) studied 63 typical prairies throughout $100,000 \mathrm{~km}^{2}$ in the central Missouri Valley region and determined little bluestem composed $58 \%$ of the grassland compared with $38 \%$ for big bluestem (A. gerardii Vitman). In the driest areas of the region where annual precipitation ranged from 61 to $66 \mathrm{~cm}$, percentages were $69 \%$ for little bluestem and $28 \%$ for big bluestem. Currently, little bluestem is dominant in many areas of the mixed-grass prairie in the northern Great Plains (Johnson and Larsen 1999), the Nebraska Sandhills, and central Kansas, Oklahoma, and Texas (Sims and Risser 2000).

The adaptation of little bluestem to dry and shallow soils across wide latitudinal and longitudinal ranges suggests it may have potential as a dedicated lignocellulosic biomass feedstock for biofuels production on land not suitable for 
annual crops or other perennial grasses, such as switchgrass (P. virgatum $\mathrm{L}$.), which are best adapted to more mesic midslopes and lowlands (Weaver and Fitzpatrick 1932). Gilbert et al. (1979) considered little bluestem to be a more stable forage producer than switchgrass under fluctuating climatic conditions.

Breeding work on little bluestem began during the late 1930s. Evaluation of strains from North Dakota to Texas in common gardens in the central Great Plains revealed ecoclinal variation for maturity, height, leafiness, and disease resistance (Anderson and Aldous 1938; Cornelius 1947). More than ten cultivars, selected populations, and source-identified populations of little bluestem have been released, with a collective range of adaptation extending from Kansas to southern Canada (Boe et al. 2004). As is the case for switchgrass and big bluestem, a strong relationship exists between latitude of origin and biomass production and winter hardiness in little bluestem. Cornelius (1947) evaluated 16 ecotypes of little bluestem with origins from Towner, ND; Vernon, TX; and Manhattan, KS. Individual spaced-plant biomass averaged across $2 \mathrm{yr}$ ranged from $130 \mathrm{~g}$ for the North Dakota ecotype to 1,563 $\mathrm{g}$ for the Texas ecotype. Spaced plants of all of the ecotypes survived the winters at Manhattan, but severe winter injury occurred on Texas and Oklahoma ecotypes in seeded plots. Phan and Smith (2000) evaluated 14 ecotypes of little bluestem from Manitoba at Winnipeg and found biomass was the highest for the southern ecotypes $\left(138 \mathrm{~g} \mathrm{plant}^{-1}\right)$ and the lowest for the northern ecotypes $\left(50 \mathrm{~g} \mathrm{plant}^{-1}\right)$. Camper, with origins in Nebraska and Kansas, has shown high winter survival in seeded trials and spaced-plant trials in the northern Great Plains (Jacobson et al. 1984; Boe and Bortnem 2009).

In a recent genetic study of biomass production of spaced plants of 22 genotypes from "Camper" little bluestem in eastern South Dakota (Boe and Bortnem 2009), differences were found among genotypes for biomass, number of phytomers per tiller, tillers plant ${ }^{-1}$, mass tiller $^{-1}$, mass of the primary axis, and mass of the axillary branches. This indicated genetic variation within Camper for biomass and yield components of biomass. Variation among genotypes for number of phytomers per tiller was likely due to withincultivar variation in maturity as a result of multiple sources from Nebraska and Kansas being used in the development of Camper. Fu et al. (2004) reported that $>91 \%$ of the total amplified fragment length polymorphism (AFLP) variation of six natural populations of little bluestem from Manitoba and Saskatchewan was within the populations. Since natural stands of little bluestem on marginal land in dry areas are highly bunchy (Weaver 1960), research to determine the impact of variation in interplant spacing on axillary branching, biomass production, seed production, water and nutrient use efficiency, and persistence is needed (Boe and Bortnem 2009).
Prairie cordgrass. Prairie cordgrass (S. pectinata Link.) is a tall, rhizomatous, perennial, warm-season species found predominantly in marshes, wet meadows, potholes, and drainage ways throughout Canada to $60^{\circ} \mathrm{N}$ latitude and throughout the continental USA, with the exceptions of Louisiana to South Carolina in the Southeast, and California, Nevada, and Arizona in the West (Hitchcock 1950; Mobberley 1956; Stubbiendieck et al. 1982). However, Mobberley (1956) frequently found prairie cordgrass in open dry prairie and on high ground along railroad rights-of-way in the Midwestern USA. The genus Spartina has the most northerly distribution of any of the $\mathrm{C} 4$ perennial grasses (Potter et al. 1995).

Prairie cordgrass is recognized for tolerance to salinity and value for wetland revegetation, stream-bank stabilization, wildlife habitat, and forage. It is adapted to soils that are too wet and not sufficiently aerated for big bluestem (A. gerardii Vitman) and switchgrass (P. virgatum $\mathrm{L}$.), grows more rapidly than other tallgrass prairie dominants, and is conspicuously taller than big bluestem and switchgrass where their distributions overlap (Weaver 1954). Weaver and Fitzpatrick (1932) noted that during the early twentieth century when the uplands and big bluestem lowlands of the tallgrass prairie were broken for growing maize (Zea mays L.), some of the soils were too wet for growing maize and were returned to growing prairie cordgrass and left mostly intact for hay production and control of soil erosion.

Although cultivars of smooth cordgrass (Spartina alterniflora Loisel.) and saltmeadow cordgrass [S. patens (Ait.) Muhl.] have been developed for coastal marsh revegetation (Alderson and Sharp 1994), the development of improved populations of prairie cordgrass for inland wetland revegetation has been very limited. "Red River Natural Germplasm" is a selected class release of prairie cordgrass from the USDA-NRCS Bismarck Plant Materials Center.

Evaluations of prairie cordgrass for biomass production at $52^{\circ} \mathrm{N}$ latitude in Europe (Potter et al. 1995), in southwestern Quebec (Madakadze et al. 1998), and in eastern South Dakota (Boe and Lee 2007) have indicated its high potential for biomass production in short-season areas, relative to switchgrass and other warm-season grasses. Its high tolerance for soil salinity and early season waterlogged soils has also been demonstrated (Montemayor et al. 2008).

In the semiarid northern Great Plains, water is the major factor controlling the growth of perennial grasses (Willis et al. 1983). As such, the highest yields of biomass from perennial grasses in the northern Great Plains would be expected to come from $\mathrm{C}_{4}$ species that establish a photosynthetically active canopy early during the growing season in an environment where soil moisture is rarely deficient. Species in the genus Spartina develop photosynthetically active canopies earlier than most other warm- 
season grasses (U.S.D.O.E. 2006) and are well-adapted to soils that are wet throughout the growing season (e.g., land capability class V). On the other hand, the other native tallgrass prairie $\mathrm{C}_{4}$ grasses are not well-adapted to those types of soils (Weaver and Ernest 1954). Therefore, prairie cordgrass, as pointed out by Weaver and Ernest (1954), should be superior to switchgrass and big bluestem for biomass production in low wet areas where it is a dominant component of the potential natural vegetation (USDA-SCS 1981). The recent 90-Billion Gallon Biofuel Deployment Study completed by Sandia National Laboratories and General Motors concluded that expanding feedstock production from dedicated biomass crops should target lands requiring little or no irrigation (DOE/Sandia National Laboratories, ScienceDaily, 11 Feb. 2009; http://HITEC transportation.org/news).

The feasibility of a billion-ton supply of biomass annually proposed by US Department of Energy (Perlack et al. 2005) assumes a high-yield scenario of an average of $18 \mathrm{Mg}$ of dry matter per hectare for perennial grass crops. In the semiarid northern Great Plains, it is highly unlikely that level of biomass production can be reached on rain fed marginal uplands. However, those levels might be attainable from high-yielding grasses on poorly drained soils (i.e., land capability class V). In South Dakota alone, there are more than 210,000 ha of land capability class V, which although too wet for conventional crop production, are generally regarded as the highest grass-producing soils in the State (D. Malo 2009, personal communication).

Maximizing biomass production in prairie cordgrass will require development of populations with the capacity to produce a high frequency of reproductive tiller across a range of environments. Mature reproductive tillers of a synthetic cultivar developed by one cycle of selection among and within seven populations from eastern South Dakota (Boe and Lee 2007) were found to exceed $2.8 \mathrm{~m}$ in height and weigh more than $30 \mathrm{~g}$ at Brookings, SD. Some of these populations out-yielded elite switchgrass cultivars in long-term studies (Fig. 1; Boe and Lee 2007). Preliminary results (unpublished data, 2008) from a biomass trial at Brookings indicated this improved population can produce $>18 \mathrm{Mg} \mathrm{ha}^{-1}$. The national goal set by US DOE for perennial grass biomass crops is at least $22 \mathrm{Mg} \mathrm{ha}^{-1}$. A stand of well-developed reproductive tillers with a mean individual weight of $30 \mathrm{~g}$ would meet that desired goal with a density of only 75 tillers $\mathrm{m}^{-2}$.

Weaver and Fitzpatrick (1932) reported reproductive culms of prairie cordgrass exceeded $3 \mathrm{~m}$ in height and $10 \mathrm{~mm}$ in diameter in wet areas in the tallgrass prairie. While few estimates exist for biomass production of prairie cordgrass in cultivated or natural stands, natural stands in the Konza prairie in northeastern Kansas produced $>15 \mathrm{Mg} \mathrm{ha}^{-1}$ (Johnson and Knapp 1996) and natural stands recovering

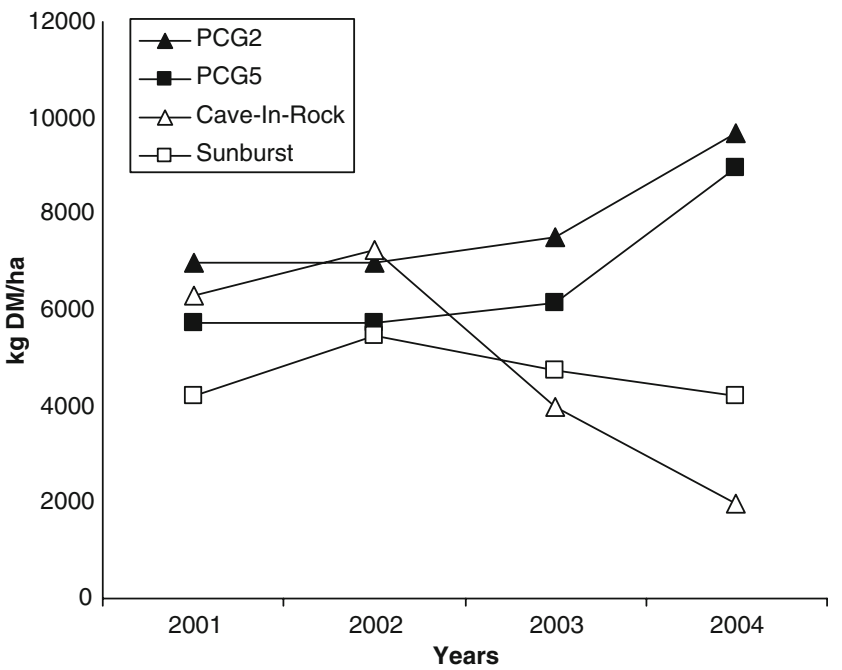

Figure 1. Mean biomass production for two natural populations of prairie cordgrass (PCG2 and PCG5) and two cultivars of switchgrass (Cave-In-Rock and Sunburst) harvested during early October 2001 thru 2004 at Aurora, SD (adapted from Boe and Lee 2007).

from long periods of drought produced $>9 \mathrm{Mg} \mathrm{ha}^{-1}$ in eastern Nebraska (Weaver and Ernest 1954).

Weaver and Ernest (1954) noted that natural stands of prairie cordgrass were not damaged from three hay harvests during a growing season, and Boe and Lee (2007) found no detrimental effects from a single harvest at the end of the growing season for transplanted stands over a 4-yr period in eastern South Dakota. Therefore, we do not expect negative impacts on mature stands from an annual single harvest during autumn for biomass production. However, studies are needed to determine the effects of multiple harvests during a growing season and $\mathrm{N}$ and $\mathrm{P}$ fertilizer on (1) reproductive tiller frequency and development, (2) biomass production, and (3) persistence of mature stands of prairie cordgrass.

Biomass production of seven populations of prairie cordgrass over $4 \mathrm{yr}$ on marginal gravelly upland in the northern Great Plains was less than one third of the production on prime land (Boe 2009, unpublished data). This reduction in biomass production was slightly greater than the reduction that occurred for Sunburst switchgrass (Fig. 1; Boe and Lee 2007). Although Mobberley (1956) considered open dry prairie and gravelly railroad embankments as primary habitats for prairie cordgrass in the Midwestern USA (as opposed to marshes, sloughs, and floodplains in the eastern USA and Canada) biomass production potential of prairie cordgrass, as well as that of switchgrass, was severely depressed on a gravelly soil in east central South Dakota. Comparisons between prairie cordgrass and switchgrass, big bluestem, little bluestem, Miscanthus, and other stress-tolerant grasses along environmental gradients are needed to determine amplitudes of 
adaptation and optimum landscape positions for species that have potential for use in an integrated multispecies approach to the establishment and maintenance of plant communities with simultaneous roles in biomass production, carbon sequestration, soil conservation, and as wildlife habitat.

\section{Genetics of North America's Prairies Perennial Grasses: A Work in Need of Progress}

Prairie cordgrass. Based on the limited amount of information available concerning the management and potential biomass productivity of prairie cordgrass and little bluestem, it is no surprise that our knowledge of genome organization and applied genetics for both species is also minimal. For example, a search of the National Center for Biotechnology Information (NCBI) database (Table 1) reveals that most of the genetic research involving either species consists of phylogenetic studies on the grasses where a limited number of DNA sequences were studied.
Prairie cordgrass has 40 chromosomes $(2 n=40, x=10)$ and is considered to be an autotetraploid (Marchant 1963, 1968), although there are no reports of detailed investigation on the mode of inheritance. A later investigation also reported octoploid accessions in the western states of the USA (Reeder 1977). This may indicate the existence of at least two different ecotypes with different ploidy levels, similar to switchgrass (Hultquist et al. 1996). The evolutionary history of the genus has been characterized by recent hybridizations and polyploidizations events (Baumel et al. 2002; Ainouche et al. 2004a, b). For example, it is believed that two new hybrid species have originated within the last $150 \mathrm{yr}$ (Ainouche et al. 2004b). Since diploid species are unknown in the Spartina genus, prairie cordgrass might have the simplest genome in the genus.

Based on DNA content values $(1 C=5.45 \mathrm{pg})$ for the dodecaploid Spartina angelica $(2 n=122,1 C=5,341 \mathrm{Mb}$; Bennett and Leitch 2005), prairie cordgrass would have an estimated DNA content of $2.8 \mathrm{pg}$. The average chromosome in the Spartina genus would have $87.6 \mathrm{Mb}$, and by extrapolation, the genome of $S$. pectinata is approximately $1,751 \mathrm{Mb}$ in size. This is equivalent to approximately four
Table 1 Number of entries in NCBI database (as on February 9, 2009) for $S$. pectinata, $S$. scoparium, and related species within both genera

\begin{tabular}{|c|c|c|c|}
\hline Species & DNA & EST & Protein \\
\hline Schizachyrium scoparium & 8 & & 3 \\
\hline Schizachyrium tenerum & 4 & & \\
\hline Schizachyrium malacostachyum & 2 & & \\
\hline Schizachyrium sanguineum & 2 & & \\
\hline Schizachyrium semitectum & 2 & & \\
\hline Schizachyrium brevifolium & 2 & & \\
\hline Schizachyrium neomexicanum & 1 & & \\
\hline Schizachyrium gaumeri & 1 & & \\
\hline Spartina alterniflora & 112 & 1,255 & 5 \\
\hline Spartina densiflora $x$ Spartina foliosa & 60 & & \\
\hline Spartina densiflora & 20 & & 4 \\
\hline Spartina pectinata & 18 & & 8 \\
\hline Spartina foliosa & 18 & & 3 \\
\hline Spartina anglica & 17 & & 7 \\
\hline Spartina gracilis & 10 & & \\
\hline Spartina patens & 10 & & 2 \\
\hline Spartina maritima & 10 & & 4 \\
\hline Spartina bakeri & 6 & & 1 \\
\hline Spartina cynosuroides & 5 & & 1 \\
\hline Spartina argentinensis & 4 & & 2 \\
\hline Spartina arundinacea & 4 & & 1 \\
\hline Spartina spartinae & 3 & & \\
\hline Spartina versicolor & 2 & & \\
\hline Spartina alterniflora $x$ Spartina densiflora & 2 & & \\
\hline Spartina ciliata & 1 & & \\
\hline Spartina $x$ townsendii & 1 & & \\
\hline
\end{tabular}


times the rice genome. At present, there is no linkage map available for any species of the Spartina genus. If we assume that prairie cordgrass has similar recombination frequencies to switchgrass, based on similar DNA content, prairie cordgrass would have a similar recombinational genetic map length of $\sim 4,500 \mathrm{cM}$ (Missaoui et al. 2005).

Very little information is available on the genome organization in Spartina spp. The only molecular marker work reported on this genus is based on randomly amplified polymorphic DNA (RAPDs), AFLPs, and intersimple sequence repeats (ISSRs) as an approach to study genetic diversity in natural populations of $S$. angelica (Ainouche et al. 2004a) and S. alterniflora (Ryan 2003; Travis and Hester 2005). A clonal germplasm collection with samples from the central prairies of North America is in development at South Dakota State University. At this time, this germplasm collection consists of clones from 128 sampling locations distributed thru South Dakota, North Dakota, Minnesota, Nebraska, Iowa, and Kansas. Future collections trips will target Missouri, Oklahoma, Texas, Arkansas, and Louisiana. An initial genetic diversity study using AFLPs on samples from the northern plains revealed extensive genetic diversity (Gonzalez-Hernandez 2009, unpublished data).

The development of molecular markers in prairie cordgrass has been nonexistent. Recent work has been done to develop a small number of simple sequence repeats (SSRs) $(<50)$ on S. alterniflora and Spartina foliosa (Blum et al. 2004; Sloop et al. 2005). When tested on S. pectinata, only a relatively low number of them amplified DNA. This observation, together with phylogenetic evidence-based DNA sequence analysis, may suggest the existence of allopolyploidy in the genus. SSR markers for prairie cordgrass are under development using a genomic library enrichment approach, consisting of enriched libraries for CA, GA, AAG, and CAG SSR repeats. An initial screening revealed an average enrichment of $65 \%$. To date, over 1,300 SSR primer pairs have been designed with most of the loci being simple repeats. We are also in the process of mapping up to 500 of them in one or two mapping populations.

The development of a linkage map for autotetraploid species like prairie cordgrass and little bluestem presents unique challenges due to the complexities of tetrasomic inheritance, namely (a) multiplex segregation, (b) double reduction, and (c) mixed bivalent and quadrivalent pairings among homologous chromosomes. These complexities translate into higher number of alleles and greater number of genotype combinations. Double reduction is a phenomenon in which sister chromatids end in the same gamete because of homologous chromosomes forming a quadrivalent, followed by crossing over between the locus and the spindle attachment. Few strategies have been developed for linkage analysis in autopolyploids. In some species such as potato (Solanun spp.; Freyre et al. 1994) and alfalfa (Medicago sativa; Diwan et al. 2000; Kalo et al. 2000) mapping can be done in diploid derivatives. The limitation of this approach stems from the fact that polyploidization and subsequent evolution is a dynamic process (Song et al. 1995); therefore, approximating a polyploidy genome to its diploid relative may not be appropriate. Another strategy is based on the segregation analysis of single-dose loci. Segregation ratios (1:1, absence versus presence) and recombination fraction of these loci in coupling are equivalent to those from disomic species. This strategy has been used with restriction fragment length polymorphisms (RFLPs) in species such as sugarcane (Saccharum spontaneum; Da Silva et al. 1993), alfalfa, and switchgrass (Missaoui et al. 2005). More recent statistical approaches have been developed assuming solely random bivalent pairing of the four homologous chromosomes (Luo et al. 2001; Cao et al. 2005). The inclusion of codominant markers, such as SSRs or RFLPs, facilitate the linkage map construction because more information about marker dosage can be derived from these markers than from dominant markers such as AFLPs which require that dosage information be inferred from the segregation ratios (Luo et al. 2001; $\mathrm{Wu}$ et al. 2001; $\mathrm{Wu}$ and $\mathrm{Ma}$ 2005; Luo et al. 2006). These approaches avoid some analytical complexities, although simultaneously ignoring essential features in tetrasomic inheritance. Currently, a methodology is being developed to solve the challenge of linkage analysis in autotetraploids (Luo et al. 2004, 2006).

A preliminary characterization of the transcriptome of prairie cordgrass is revealing a great level of similarity with other grasses in general and sorghum in particular. Taking advantage of recent sequencing technologies developments, we conducted a transcriptome analysis using a normalized pooled full-length cDNA library from four tissues which yielded approximately 26,000 contigs representing a little over 10,000 unigenes (Gonzalez-Hernandez 2009, unpublished data).

We have discussed in previous sections the importance of using soils currently out of intensive production to exploit salinity tolerance of prairie cordgrass. This trait is shared by all Spartina species. In fact, most species in the genus are salt marsh species. This observation opens the question on how some Spartina species such as $S$. pectinata and Spartina gracilis (alkali cordgrass) colonized the interior prairies of North America. Recent studies (Baisakh et al. 2006; Baisakh et al. 2008) in S. alterniflora have provide evidence that, in addition to several previously unknown genes, genes involved in ion transport, osmolyte production, and housekeeping functions may play an important role in the primary responses to salt stress in this halophyte grass. The study of these genes in prairie cordgrass is the logical starting point to study the salt 
tolerance of this species and could have a significant impact in the development of highly productive varieties.

Little bluestem. Investigations into the genome of little bluestem is also limited. It is considered a tetraploid with the chromosome number and ploidies were determined as $2 n=40$ (Bruner 1983). The utilization of molecular markers to determine genetic diversity among populations of little bluestem has occurred, although it was proposed that due to the outcrossing mode of reproduction of this species, resulting in highly heterogeneous populations, ascertaining an accurate representation of the genetic diversity of little bluestem would be difficult (Huff et al. 1998; Fu et al. 2004). It is postulated that the phenotype of little bluestem is independently and continuously variable across its range of habitation without discernable regional delineation (Wipff 1996).

Huff et al. (1998) examined RAPD variation among four populations which were derived from soils of high and low fertility with two geographic locations: New Jersey (a forest biome) and Oklahoma (a grassland biome). This study examined the genetic diversity in reference to using little bluestem for restoration and revegetation as concern was raised that commercially produced cultivars of little bluestem would have a limited germplasm base and have a restricted applicability for revegetation. Ten plants were sampled from each of the four populations and tiller material was collected from each plant for DNA extraction (Huff et al. 1998). Four RAPD markers were analyzed. Although this study is limited by the small number of RAPD markers used, analysis of molecular variance of polymorphic RAPDs indicated that there was significant genetic differences between the four populations $(p<0.05)$, with the greatest genetic distance between the New Jersey high fertility population and the Oklahoma low fertility population (Huff et al. 1998). However, Huff et al. (1998) observed a relatively low level of population differentiation among the four little bluestem populations in comparison to other outcrossing species. It is assumed that a high level of genetic variability caused this low level of differentiation, maintained by frequent outcrossing and the ability of the species to have very long distance pollen and seed dispersal.

A second study into the genetic diversity of little bluestem was performed by $\mathrm{Fu}$ et al. (2004), utilizing AFLPs. In this study, the population examined was from the extreme north of the geographic range of bluestem, with all samples collected north of the $49^{\circ}$ parallel in western Canada. From six locations, 30 plants were randomly selected for tissue collection (Fu et al. 2004). One of the goals of this research, similar to that of Huff et al. (1998), was to assess the genetic diversity of natural populations, with congruent concerns about improved plant materials not maintaining a level of genetic diversity requisite for adaptation to a new environment (Fu et al. 2004). Tissue for DNA extraction was collected from the plants and analyzed with five primer combinations, creating 158 scorable polymorphic bands (Fu et al. 2004). Results from the analysis indicated that a small yet significant $(p<0.01)$ amount of genetic variation was discernable among the six populations (Fu et al. 2004). However, the genetic diversity was not correlated with geographical distances of the collection sites ( $r=0.02, p=0.5244$; Fu et al. 2004).

Consistent between the studies performed by Huff et al. (1998) and Fu et al. (2004) was the considerable difference between within and among population genetic diversity. Huff et al. (1998) found 95\% of total genetic variation resided within a population, while only $5 \%$ resided among the examined populations. Similarly, Fu et al. (2004) found $92.8 \%$ of the total genetic variation resided within a population, while $7.2 \%$ resided among the six populations examined. Both these results confirm the highly outcrossing nature of little bluestem.

Little bluestem has been successfully cultured in vitro (Songstad et al. 1986). Young inflorescence from three genotypes were used to develop callus culture on RM medium (Linsmaier and Skoog 1965) supplemented with $5 \mathrm{mg} \mathrm{l}^{-1}$ of 2,4-D, and the transfer of the callus tissue onto hormone-free media induced organogenesis (Songstad et al. 1986). Plant development was found to have been via somatic embryogenesis, and the explants were transplanted into pots in the greenhouse where they grew to maturity in 24 wk (Songstad et al. 1986). While no reports of transformation of little bluestem have been found, the results of Songstad et al. (1986) indicate that viable embryogenic callus, suitable for transformation, can be grown as in many other grasses.

\section{Potential Pathogens and Pets of Perennial Feedstocks}

As with all of the previously discussed topics, there is very little information currently available concerning the known or potential pathogens and pests of herbaceous perennial feedstocks, especially prairie cordgrass and little bluestem. As a result, much of what will be discussed in this section will be conjecture based on historical surveys and research in related species. What is well-documented is that pathogens and pests can have significant lasting impacts on biomass productivity and stand survival in crops harvested for biomass, such as alfalfa (M. sativa L.; Nutter et al. 2002), and therefore, researchers need to understand the potential impact of these organisms on all potential feedstock species. There is little doubt that economical management strategies need to be developed in order to 
mitigate any losses from feedstock pathogens and pests. Failure to do so could jeopardize the sustainability of this emerging industry.

The reason that pathogens and pests are a potential concern for perennial feedstock crops can be summarized by one word: monoculture. When little bluestem, prairie cordgrass, switchgrass, and most other feedstock species were found in their native ecosystem(s), there was usually some level of heterogeneity in terms of both species diversity and genetic uniformity within each species (Fu et al. 2004; Kittelson and Handler 2006; Polley et al. 2007). That is, individuals of one species were not usually the only plants within a given area, and if they were, it was common that multiple genetically unique individuals were present. This diversity impacted the occurrence and importance of pathogens and pests because reproduction and spread of these organisms is often dependent on the density and uniformity of the host (Young 1995; Garrett and Mundt 1999; Mitchell et al. 2002). For example, a single uredinia (pustule) of the rust fungus Puccinia sparganioides (Ash-Cordgrass rust) can produce thousands of urediniospores and these propagules can easily become airborne.

However, the probability that any given spore will land on a susceptible host (namely prairie cordgrass) is inversely proportional to the density and diversity of the host species in a given area. In other words, if another susceptible host is too far away from the infected source plant, then the chances of the epidemic progressing to a substantial level are minimal. In contrast, monocultures are composed of single plant species that are often very genetically uniform. This greatly increases the chance that pathogens and pests will be able to spread within a given location and more importantly that such organisms can become highly adapted to a given host genotype and impact the crop even more dramatically. The loss of genetic variability through the process of selection and varietal improvement and the subsequent planting of crop monocultures are the primary reasons why pathogens and pests should be study extensively in perennial feedstock crops.

A variety of fungi and water molds, bacteria and mollicutes, protozoa, and nematodes can be pathogenic to plants and there are also several virus and viroid groups that utilize plants as a host. Similarly, many different insect and mite species can feed on plants and cause damage. The potential effects of diseases and pests on herbaceous perennial feedstock crops like prairie cordgrass and little bluestem can be organized into three general groupings based on what the final impact(s) will be (a) photosynthetic capacity, (b) plant-water relations, and (c) seed production and viability. It should be noted that these groupings are not mutually exclusive but are simply used in this review to partition impacts into concise categories.

The most obvious impact in terms of economic importance to feedstock crops is the disruption of photo- synthetic capacity. Specifically, if the ability of a plant to photosynthesize is reduced, then the potential to produce aboveground biomass will be limited. Reductions can occur through physical means, such as when a pest feeds on a leaf. A prime example would be locust swarms where complete or near-complete defoliation of plants is known to occur, often over enormous regions (Stewart 1997; Todd et al. 2002; Ceccato et al. 2007). Reductions may also occur when a plant is parasitized by a pathogen and both prairie cordgrass and little bluestem have been documented to be susceptible to multiple foliar pathogens (Mankin 1969; Farr and Rossman 2009), some of which are highly specific (e.g., P. sparganioides on prairie cordgrass). In addition to pathogens, natural stands of prairie cordgrass have also been found to be heavily infested with insects, such as the lygaied Ischnodemus falicus (Johnson and Knapp 1996; Boe and Stein 2008, unpublished data). This piercingsucking bug reduced biomass production of natural stands of prairie cordgrass by $40 \%$ in Kansas (Johnson and Knapp, 1996) and could become economically important as the feedstock industry develops.

Reductions may also be physiological such as when plants are infected by a virus or phytoplasma and it has long been known that leaves showing mosaic symptoms of viral infection (i.e., yellowing) usually have reduced photosynthetic rates (Diener 1963; Balachandran et al. 1997) and therefore lowered photosynthetic capacity. No viruses have been found in prairie cordgrass and only one virus has been identified in little bluestem to date, maize streak monogeminivirus (Brunt et al. 1996). However, the lack of known viruses in these species does not necessarily mean that none are present; instead, it is quite possible that additional viruses do exist in these but have yet to be found because no one has looked. For example, Spartina mottle rymovirus has been documented in related Spartina species in Europe (Brunt et al. 1996) and during the aforementioned germplasm collection trips, we found prairie cordgrass plants with leaf mottling symptoms at approximately $10 \%$ of the locations (Stein 2009, unpublished data). When these samples were submitted for commercial virus testing, they all came back negative for a number of common grass viruses (Stein 2009, unpublished data). Spartina mottle rymovirus was not part of the panel and therefore, further investigations in this topic are planned.

In addition to strictly physical and physiological disruptions, there are a number of plant pathogens and pests that initially cause physiological impacts (localized chlorosis) but ultimately cause tissue death (blighting). Many of these organisms produce toxins that initially impact cell physiology but can eventually kill the affected tissue (Orolaza et al. 1995; Young et al. 1992). This type of damage is functionally equivalent to direct tissue removal and can have similar impacts on biomass accumulation. 
Prairie cordgrass has at least two fungal pathogens of this type: Septoria spartinae and Stagonospora spartinicola and little bluestem one: Pyrenophora tritici-repentis. These organisms produce leaf spot/blight symptoms and have the potential to cause economic losses in production (Farr and Rossman 2009; Mankin 1969). As with the viruses, more species will likely be found as research efforts in the area are expanded (Leslie et al. 2004).

As with photosynthetic capacity, the disruption of plantwater relations by pathogens or pests can have profound impacts on biomass production in a feedstock crop. Symptoms can include stunting or wilting of the plant, nutrient deficiency in the foliage, and even lodging (breakage of the stem), all of which reduce harvestable biomass. The first and most obvious is the loss or disruption of root function through pest feeding or rot. Many fungi and insect genera are known to cause significant problems in other grasses but few have been documented in prairie cordgrass and little bluestem. Plant parasitic nematodes, on the other hand, have been known to be important in native prairie ecosystems for some time (Smolik 1973). For example, the application of a nematicide to experimental plots containing little bluestem resulted in a significant increase in ANPP for two seasons (Ingham and Detling 1990). No nematode pests have been noted in prairie cordgrass, but others have been found to be important in other Spartina spp. (Plantard et al. 2007). Based on historical evidence and occurrences of nematodes in other cropping systems (Smiley et al. 2006), it is highly likely that they would become important under intensive production systems with little bluestem and possibly even prairie cordgrass.

Unlike nematodes, only a few primary root rotting fungal pathogens have been found in little bluestem (Farr and Rossman 2009; Leslie et al. 2004; Mankin 1969) and none have been confirmed to date in prairie cordgrass (Farr and Rossman 2009; Mankin 1969), although several fungal species that are important in other cropping systems (such a Bipolaris) have been isolated from root tissue of the latter (Stein 2009, unpublished data). As before, the lack of known pathogens and pests does not necessarily mean that none will become important in the future; instead, further research needs to be conducted in this topic area because these organisms limit productivity. For example, Fusarium root and crown rot was found to reduce wheat grain yields by $25 \%$ under field conditions in the Pacific Northwest (Smiley et al. 2006) and similar losses have been noted from rootworm (Diabrotica spp.) damage in maize (Riedell et al. 1992). Successful implementation of biotechnology tools has resulted in production of maize resistant to corn rootworm, which producers prefer stacked with biotech traits for control of European corn borer and herbicide tolerance-referred together as a triple stack (James 2008).
Systemic viral infections are also known to disrupt root function and may impact biomass accumulation, but their important is unknown since few have been found to infect prairie cordgrass and little bluestem (Brunt et al. 1996), as noted above. Nevertheless, use of biotechnology to solve these issues is a viable option based on the efforts over the past $25 \mathrm{yr}$ with biotech maize.

A similar mechanism of disruption involves water movement in the plant. Specifically, there are several pathogen and pest groups that colonize stems and impede water translocation (upward movement). For example, prairie cordgrass has been documented to have several stem boring moths that are specialists on the species (Reed 1996). During our recent summer disease surveys (in 2007 and 2008), evidence of stem borer activity was found at nearly all of the sampling sites and was quite severe in one large patch of prairie cordgrass. At this location, nearly $50 \%$ of the tillers were lodged due to excessive damage (Stein 2009, unpublished data); however, this was late in the growing season and so it is unknown if a significant reduction in biomass accumulation occurred.

The final impact of plant pathogens and pests on feedstock crops is seed production and viability. This is the least obvious because the ability of a feedstock crop to make viable seed is usually not important in terms of biomass productivity; however, for fertile species such as prairie cordgrass and little bluestem, the most economical way to establish crops will be through seeding. Therefore, a source of uniform viable seed will need to be maintained to support this industry. Seed production is highly dependent on overall plant health and therefore, the previous list of impacts to biomass production would also apply in this case. There are also pathogens and pests that can be directly limiting in this area. For example, several types of insects and also some birds are known to feed on the seeds of these species. This is an obvious direct loss in productivity in terms of a seed crop. Smut/bunt fungi in other grass species are also well-documented to impact seed production and in some cases plant biomass (Gravert et al. 2000). Prairie cordgrass does not have any known smut/bunts pathogens; however, Sorosporium ellissii has been identified in little bluestem (Farr and Rossman 2009; Mankin 1969) and might become important in a seed production situation. The disease ergot, caused by the fungus Claviceps spp., has also been documented in both prairie cordgrass and little bluestem (Alderman et al. 2004) and might be sporadically important in seed production.

Plant pathogens and pests could severely impact the establishment, productivity, and even sustainability of herbaceous feedstock crops such as prairie cordgrass and little bluestem. It is vital that research be expanded in this area so that breeders, pathologists, agronomists, and 
growers are better prepared to deal with such issues as varieties are developed, released, and large-scale production begins. The first and probably most important is the continuation of disease and pest surveys over large geographical areas so that we can get a more thorough understanding of which organisms could become important in the future. This should include prairie cordgrass and little bluestem stands that are both naturally and artificially established in a variety of locations, soil types, and microclimes. Once a list of potential organisms is compiled, studies will then need to be conducted on individual species so that the research community can better understand the biology of each organism. Better-informed decisions can then be made concerning breeding strategies and planting, crop management, and biomass harvest timing. For example, if one can determine that the development of physiological races is likely to occur in $P$. sparganioides on prairie cordgrass (i.e., virulence on specific resistance genes), then one will know that breeding efforts should focus on durable rust resistance, gene pyramiding, and/or the development of multilines which vary significantly in the gene(s) responsible for rust resistance (McDonald and Linde 2002; Mundt 2002; Parker and Gilbert 2004). Such research has historically been conducted using traditional genetic analysis; however, the use of modern genomics tools in this field could accelerate our efforts and allow us to be one step ahead of the potential pathogens and pests of prairie cordgrass and little bluestem.

\section{Summary}

It is clear that meeting the new expectations from bioenergy crops while concurrently increasing food production for an increasing global human population will demand not only an increased productivity of food crops in current cropland, but the use of class $\mathrm{V}$ soils for biofuel production of prairie cordgrass and little bluestem. The literature suggests that these species have received little attention even though they can be more productive in particular marginal lands than other species being considered, such as switchgrass. The work needed to develop these other native species into competitive dedicated biomass crops should focus around a rapid development of highly productive cultivars coupled with the development of sustainable agronomic practices. Studies focusing on the biology, genetics, and natural variability of traits determining biomass yield are urgently needed.

Recent agricultural history reminds us of the importance of plant pathogens and pests. We know that sooner rather than later all crops, when grown in large areas, will become susceptible to the attack of pathogens of different nature and to changes in insect populations. To prevent epidemics, it is imperative that the scientific community takes a proactive approach.

Although the development of transgenic cultivars is feasible in switchgrass and Miscanthus, transformation in these and other potential species has not been extensively attempted. In addition, the widespread release of transgenic cultivars of native perennial grasses may face a great deal of opposition due to potential environmental and regulatory issues.

\section{References}

Ainouche M. L.; Baumel A.; Salmon A. Spartina angelica c. E. Hubbard: A natural model system for analysing early evolutionary changes that affect allopolyploid genomes. Biol. J. Linn. Soc. 82: 475-484; 2004a. doi:10.1111/j.1095-8312.2004.00334.x.

Ainouche M. L.; Baumel A.; Salmon A.; Yannic G. Hybridization, polyploidy and speciation in Spartina (Poaceae). New Phytol. 161: 165-172; 2004b. doi:10.1046/j.1469-8137.2003.00926.x.

Alderman S. C.; Halse R. R.; White J. F. A reevaluation of the host range and geographical distribution of Claviceps species in the United States. Plant Dis. 88: 63-81; 2004. doi:10.1094/ PDIS.2004.88.1.63.

Alderson J.; Sharp W. C. Grass varieties in the United States. USDASCS, Washington, DC1994.

Al-Kaisi M. M.; Grote J. B. Cropping system effects on improving soil carbon stocks of exposed subsoil. Soil Sci. Soc. Am. J. 71: 1381-1388; 2007. doi:10.2136/sssaj2006.0200.

Anderson W. F.; Dien B. S.; Brandon S. K.; Peterson J. D. Assessment of bermudagrass and bunch grasses as feedstock for conversion to ethanol. Appl. Biochem. Biotechnol. 145: 13-21; 2008. doi:10.1007/s12010-007-8041-y.

Anderson K. L.; Aldous A. Improvement of Andropogon scoparius Michx. By breeding and selection. J. Am. Soc. Agronom. 30: $862-869 ; 1938$.

Baisakh N.; Subudhi P. K.; Parami N. P. cDNA-AFLP analysis reveals differential gene expression in response to salt stress in a halophyte Spartina alterniflora Loisel. Plant Sci. 170: 11411149; 2006. doi:10.1016/j.plantsci.2006.02.001.

Baisakh N.; Subudhi P.; Varadwaj P. Primary responses to salt stress in a halophyte, smooth cordgrass (Spartina alterniflora Loisel.). Funct. Integr. Genom. 8: 287-300; 2008. doi:10.1007/s10142008-0075-x.

Balachandran S.; Hurry V. M.; Kelley S. E.; Osmond C. B.; Robinson S. A.; Rohozinski J.; Seaton G. G. R.; Sims D. A. Concepts of plant biotic stress. Some insights into the stress physiology of virus-infected plants, from the perspective of photosynthesis. Physiol Plant 100: 203-213; 1997. doi:10.1111/j.13993054.1997.tb04776.x.

Barney J. N.; Ditomaso J. M. Nonnative species and bioenergy: are we cultivating the next invader? Bioscience 58: 64-70; 2008. doi:10.1641/B580111.

Baumel A.; Ainouche M. L.; Bayer R. J.; Ainouche A. K.; Misset M. T. Molecular phylogeny of hybridizing species from the genus Spartina Schreb. (Poaceae). Mol. Phylogenet. Evol. 22: 303-314; 2002. doi:10.1006/mpev.2001.1064.

Bennett, M. D.; Leitch, I. J. Plant DNA c-values database (release 4.0, Oct. 2005); 2005.

Blum M. J.; Sloop C. M.; Ayres D. R.; Strong D. R. Characterization of microsatellite loci in Spartina species (Poaceae). Mol. Ecol. Notes 4: 39-42; 2004. doi:10.1046/j.1471-8286.2003.00556.x. 
Boe A.; Bortnem R. Morphology and genetics of biomass in little bluestem. Crop Sci. 49: 411-418; 2009.

Boe A.; Keeler K. H.; Normann G. A.; Hatch S. L. The indigenous bluestems of the western hemisphere and gambagrass. In: Moser L.; Burson B.; Sollenberger L. (eds) Warm-season $\left(\mathrm{c}_{4}\right)$ grasses. ASA, Madison, WI, pp 873-908; 2004.

Boe A.; Lee D. K. Genetic variation for biomass production in prairie cordgrass and switchgrass. Crop Sci. 47: 929-934; 2007.

Bouton J. H. Molecular breeding of switchgrass for use as a biofuel crop. Curr. Opin. Genet Dev. 17: 553-558; 2007. doi:10.1016/j. gde.2007.08.012.

Bruner, J. Systematics of the Schizachyrium scoparium group (Poaceae) in North America. Am. J. Bot. 70 Part 2. (5): 108; 1983.

Brunt A.; Crabtree K.; Dallwitz M.; Gibbs A.; Watson L. Viruses of plants: descriptions and lists from the VIDE database. CAB International, Wallingford, UK; 1996.

Cao D.; Craig B.; Doerge R. A model selection-based interval mapping method for autotetraploids. Genetics 169: 2371-2382; 2005. doi:10.1534/genetics. 104.035410 .

Cardona Ca; Sanchez O. J. Fuel ethanol production: Process design trends and integration opportunities. Bioresour. Technol. 98: 2415-2457; 2007. doi:10.1016/j.biortech.2007.01.002.

Cassman K. G.; Liska A. J. Food and fuel for all: Realistic or foolish? Biofuels Bioprod Bioref 1: 18-23; 2007. doi:10.1002/bbb.3.

Ceccato P.; Cressman K.; Giannini A.; Trzaska S. The desert locust upsurge in West Africa (2003-2005): Information on the desert locust early warning system and the prospects for seasonal climate forecasting. Int. J. Pest Manag. 53: 7-13; 2007. doi:10.1080/09670870600968826.

Ceotto, E. Grasslands for bioenergy production: A review. Agron. Sustain. Dev. 28: 47-55; 2008.

Chen F.; Dixon R. A. Lignin modification improves fermentable sugar yields for biofuel production. Nat. Biotechnol. 25: 759-761; 2007. doi:10.1038/nbt1316.

Christian D. G.; Riche A. B.; Yates N. E. Growth, yield and mineral content of Miscanthus $x$ giganteus grown as a biofuel for 14 successive harvests. Ind. Crop Prod. 28: 320-327; 2008. doi:10.1016/j.indcrop.2008.02.009.

Cornelius D. R. The effect of source of little bluestem grass seed on growth, adaptation, and use in revegetation seeding. J. Agric. Res. 74: 133-143; 1947.

Da Silva J.; Sorrells M.; Burnquist W.; Tanskley S. RFLP linkage map and genome analysis of Saccharum spontaneum. Genome 36: 182-791; 1993.

Demirbas A. Recent progress in biorenewable feedstocks. Energy Educ. Sci. Technol. 22: 69-95; 2008.

Dien B. S.; Jung H. J. G.; Vogel K. P.; Casler M. D.; Lamb J. F. S.; Iten L.; Mitchell R. B.; Sarath G. Chemical composition and response to dilute-acid pretreatment and enzymatic saccharification of alfalfa, reed canarygrass, and switchgrass. Biomass Bioenergy 30: 880-891; 2006. doi:10.1016/j.bio mbioe. 2006.02.004.

Diener T. Physiology of virus-infected plants. Annu. Rev. Phytopathol. 1: 197-218; 1963. doi:10.1146/annurev.py.01.090163.001213.

Diwan N.; Bouton J.; Kochert G.; Creagan P. Mapping of simple sequence repeat (SSR) DNA markers in diploid and tetraploid alfalfa. Theor. Appl. Genet. 101: 165-172; 2000. doi:10.1007/ s001220051465.

Doolittle J. J.; Malo, D. D., Kunze, B. O.; Winter, S. D.; Schaefer Jr., W. T.; Millar, J. B.; Shurtliff, D. R. Land judging in South Dakota. ABS 8-01; South Dakota State Univ.; 2002.

Evanylo G. K.; Abaye A. O.; Dundas C.; Zipper C. E.; Lemus R.; Sukkariyah B.; Rockett J. Herbaceous vegetation productivity, persistence, and metals uptake on a biosolids-amended mine soil. J. Environ. Qual. 34: 1811-1819; 2005. doi:10.2134/ jeq2004.0329.
Fargione J.; Hill J.; Tilman D.; Polasky S.; Hawthorne P. Land clearing and the biofuel carbon debt. Science 319: 1235-1238; 2008. doi: $10.1126 /$ science. 1152747.

Farr D. F.; Rossman A. Y. Fungal databases. Systematic Mycology and Microbiology Laboratory, ARS, USDA, Baltimore; 2009.

Freyre R.; Warnke S.; Sosinski B.; Douches D. Quantitative trait locus analysis of tuber dormancy in diploid potato (Solanun spp). Theor. Appl. Genet. 89: 474-480; 1994. doi:10.1007/BF00225383.

Fu Y. B.; Phan A. T.; Coulman B.; Richards W. Genetic diversity in natural populations and corresponding seed collections of little bluestem as revealed by AFLP markers. Crop Sci. 44: 2254-2260; 2004.

Garrett Ka; Mundt C. C. Epidemiology in mixed host populations. Phytopathology 89: 984-990; 1999. doi:10.1094/PHYTO. 1999.89.11.984

Gaunt J. L.; Lehmann J. Energy balance and emissions associated with biochar sequestration and pyrolysis bioenergy production. Environ. Sci. Tech. 42: 4152-4158; 2008. doi:10.1021/es071361i.

Gilbert W. L.; Perry L. J.; Stubbiendieck J. Dry matter accumulation of four warm season grasses in the Nebraska sandhills. J. Range Manag.52-54; 1979. doi:10.2307/3897385.

Gomez L. D.; Steele-King C. G.; McQueen-Mason S. J. Sustainable liquid biofuels from biomass: The writing's on the walls. New Phytol. 178: 473-485; 2008. doi:10.1111/j.1469-8137.2008.02422.x.

Gravert C.; Tiffany L.; Munkvold G. Outbreak of smut caused by Tilletia maclaganii on cultivated switchgrass in Iowa. Plant Dis. 84: 596; 2000. doi:10.1094/PDIS.2000.84.5.596A.

Heaton E.; Clifton-Brown J. C.; Voigt T.; Jones M.; Long S. P. Miscanthus for renewable energy generation: European Union experience and projections for Illinois. Mitig. Adapt. Strategies Glob. Chang. 9: 433-451; 2004. doi:10.1023/B:MITI. 0000038848.94134.be.

Heaton E. A.; Dohleman F. G.; Long S. P. Meeting US biofuel goals with less land: The potential of Miscanthus. Glob. Chang. Biol. 14: 2000-2014; 2008. doi:10.1111/j.1365-2486.2008.01662.x.

Hitchcock A. S. Manual of the grasses of the United States. USDA Misc. Pub. No. 200. U.S. Gov. Print. Office, Washington, D.C. 1935

Hockensmith R. D.; Steele J. G. Recent trends in the use of the landcapability classification. Soil Sci. Soc. Amer. J. 14: 383-388; 1950.

Huff D. R.; Quinn J. A.; Higgins B.; Palazzo A. J. Random amplified polymorphic DNA (RAPD) variation among native little bluestem [Schizachyrium scoparium (Michx.) Nash] populations from sites of high and low fertility in forest and grassland biomes. Mol. Ecol. 7: 1592-1597; 1998. doi:10.1046/j.1365294x.1998.00473.x.

Hultquist S. J.; Vogel K. P.; Lee D. J.; Arumuganathan K.; Kaeppler S. Chloroplast DNA and nuclear DNA content variations among cultivars of switchgrass, Panicum virgatum L. Crop Sci. 36: 1049-1052; 1996.

Ingham R. E.; Detling J. K. Effects of root-feeding nematodes on aboveground net primary production in a North American grassland. Plant Soil 121: 279-281; 1990. doi:10.1007/BF00012321.

Jacobson E. T.; Tober D. A.; Haas R. J.; Darris D. C. The performance of selected cultivars of warm season grasses in the northern prairie and plains states. In: Clambey G. K.; Pemble R. H. (eds) The 9th North American Prairie Conference. Tri-College University Centre for Environmental Studies, Moorhead, MN, pp 215-221; 1984

James C. Global status of commercialized biotech/GM crops. ISAAA Brief Number 39. ISAAA, Ithaca, NY2008.

Johnson S. R.; Knapp A. K. Impact of Ischnodemus falicus (Hemiptera: Lygaeidae) on photosynthesis and production of Spartina pectinata wetlands. Environ. Entomol. 25: 1122-1127; 1996.

Johnson J. R.; Larsen G. E. Grassland plants of South Dakota and the northern great plains. South Dakota Agricultural Experiment Station, South Dakota State University, Brookings, SD1; 999. 
Kalo P.; Endre G.; Zimanyi L.; Csnadi G.; Kiss G. Construction of an improved linkage map of diploid alfalfa (Medicago sativa)Theor. Appl. Genet. 100: 641-657; 2000.

Keshwani D. R.; Cheng J. J. Switchgrass for bioethanol and other value-added applications: A review. Bioresour. Technol. 100: 1515-1523; 2009. doi:10.1016/j.biortech.2008.09.035.

Kittelson P. M.; Handler S. D. Genetic diversity in isolated patches of the tallgrass prairie forb, Lithospermum canescens (Boraginaceae). J. Torrey Bot. Soc. 133: 513-518; 2006. doi:10.3159/10955674(2006)133[513:GDIIPO]2.0.CO;2.

Knapp A. K.; Briggs J. M.; Blair J. M.; Turner C. L. Patterns and controls of aboveground net primary production in tallgrass prairie. In: Knapp A. K. (ed) Grassland dynamics: Long-term ecological research in tallgrass prairie. Oxford University Press, Oxford, UK; 1998.

Leslie J. F.; Zeller K. A.; Logrieco A.; Mule G.; Moretti A.; Ritieni A. Species diversity of and toxin production by Gibberella fujikuroi species complex strains isolated from native prairie grasses in Kansas. Appl. Environ. Microbiol. 70: 2254-2262; 2004. doi:10.1128/AEM.70.4.2254-2262.2004.

Linsmaier E. M.; Skoog K. Organic growth factor requirement for tobacco tissue cultures. Physiol. Plant 18: 100-127; 1965. doi:10.1111/j.1399-3054.1965.tb06874.x.

Luo Z. W.; Hackett C. A.; Bradshaw J. E.; McNichol J. W.; Milbourne D. Construction of a genetic linkage map in tetraploid species using molecular markers. Genetics 157: 1369-1385; 2001.

Luo Z. W.; Zhang R. M.; Kearsey M. J. Theoretical basis for genetic linkage analysis in autotetraploid species. Proc. Natl. Acad. Sci. U. S. A. 101: 7040-7045; 2004. doi:10.1073/pnas.0304482101.

Luo Z. W.; Zhang Z.; Leach L.; Zhang R. M.; Bradshaw J. E.; Kearsey M. J. Constructing genetic linkage maps under a tetrasomic model. Genetics 172: 2635-2645; 2006. doi: 10.1534/genetics.105.052449.

Madakadze I. C.; Coulman B. E.; Mcelroy A. R.; Stewart K. A.; Smith D. L. Evaluation of selected warm-season grasses for biomass production in areas with a short growing season. Bioresour. Technol. 65: 1-12; 1998. doi:10.1016/S0960-8524(98)00039-X.

Mankin C. J. Diseases of grasses and cereals in South Dakota: a check list. Agricultural Experiment Station, South Dakota State University, Brookings, SD, p 28; 1969.

Marchant C. J. Corrected chromosome numbers for Spartina $x$ townsendii and its parents. Nature 199: 929; 1963. doi:10.1038/199929a0.

Marchant C. J. Evolution in Spartina (Gramineane). III. Species chromosome numbers and their taxonomic significance. Bot. J. Linn. Soc. 60: 411-417; 1968. doi:10.1111/j.1095-8339.1968. tb00097.x.

Martinez-Reyna J. M.; Vogel K. P. Heterosis in switchgrass: spaced plants. Crop Sci. 48: 1312-1320; 2008. doi:10.2135/ cropsci2007.12.0695.

Masters R. A.; Mislevy P.; Moser L. E.; Rivas-Pantoja F. Stand establishment. In: Moser L. E.; Burson B. L.; Sollenberger L. E. (eds) Warm-season $\left(\mathrm{C}_{4}\right)$ grasses. Agronomy Monograph No. 45. ASA, CSSA, SSSA, Madison, WI, pp 145-178; 2004.

McDonald B. A.; Linde C. Pathogen population genetics, evolutionary potential, and durable resistance. Annu. Rev. Phytopathol. 40: 349-379; 2002. doi:10.1146/annurev.phyto.40.120501.101443.

McLaughlin S. B.; Kszos L. A. Development of switchgrass (Panicum virgatum) as a bioenergy feedstock in the United States. Biomass Bioenergy 28: 515-535; 2005. doi:10.1016/j.biombioe.2004.05.006.

Missaoui A. M.; Paterson A. H.; Bouton J. H. Investigation of genomic organization in switchgrass (Panicum virgatum L.) using DNA markers. Theor. Appl. Genet. 110: 1372-1383; 2005. doi:10.1007/s00122-005-1935-6.

Mitchell C. E.; Tilman D.; Groth J. V. Effects of grassland plant species diversity, abundance, and composition on foliar fungal disease. Ecology 83: 1713-1726; 2002.
Mobberley D. G. Taxonomy and distribution of the genus Spartina. Iowa State Coll. J. Sci. 30: 471-574; 1956.

Montemayor M. B.; Price J. S.; Rochefort L.; Boudreau S. Temporal variations and spatial patterns in saline and waterlogged peat fields. Environ. Exp. Bot. 62: 333-342; 2008.

Mulkey V. R.; Owens V. N.; Lee D. K. Management of switchgrassdominated conservation reserve program lands for biomass production in South Dakota. Crop Sci. 46: 712-720; 2006. doi:10.2135/cropsci2005.04-0007.

Mulkey V. R.; Owens V. N.; Lee D. K. Management of warm-season grass mixtures for biomass production in South Dakota USA. Bioresour. Technol. 99: 609-617; 2008. doi:10.1016/j.biortech.2006.12.035.

Mundt C. C. Use of multiline cultivars and cultivar mixtures for disease management. Annu. Rev. Phytopathol. 40: 381-410; 2002. doi:10.1146/annurev.phyto.40.011402.113723.

Nutter F. W.; Guan J.; Gotlieb A. R.; Rhodes L. H.; Grau C. R.; Sulc R. M. Quantifying alfalfa yield losses caused by foliar diseases in Iowa, Ohio, Wisconsin, and Vermont. Plant Dis. 86: 269-277; 2002. doi:10.1094/PDIS.2002.86.3.269.

Orolaza N. P.; Lamari L.; Balance G. M. Evidence of a host-specific chlorosis toxin from Pyrenophora-tritici-repentis, the causal agent of tan spot of wheat. Phytopathology 85: 1282-1287; 1995. doi:10.1094/Phyto-85-1282.

Parker I. M.; Gilbert G. S. The evolutionary ecology of novel plantpathogen interactions. Annu. Rev. Ecol. Evol. Syst. 35: 675-700; 2004. doi:10.1146/annurev.ecolsys.34.011802.132339.

Parrish D. J.; Fike J. H. The biology and agronomy of switchgrass for biofuels. Crit. Rev. Plant Sci. 24: 423-459; 2005. doi:10.1080/ 07352680500316433 .

Perlack R.; Wright L.; Turhollow A.; Graham R.; Stokes B.; Erbach D. Biomass as feedstock for a bioenergy and bioproducts industry: the technical feasibility of a billion-ton annual supply. U.S. Dept. of Commerce, Springfield, VA; 2005.

Phan A. T.; Smith Jr. S. R. Seed yield variation in blue grama and little bluestem plant collections in southern Manitoba, Canada. Crop Sci. 40:555-561; 2000.

Plantard O.; Valette S.; Gross M. F. The root-knot nematode producing galls on Spartina altemiflora belongs to the genus Meloidogyne: Rejection of Hypsoperine and Spartonema spp. J. Nematol. 39: 127-132; 2007.

Polley H. W.; Wilsey B. J.; Derner J. D. Dominant species constrain effects of species diversity on temporal variability in biomass production of tallgrass prairie. Oikos 116: 2044-2052; 2007. doi:10.1111/j.2007.0030-1299.16080.x.

Potter L.; Bingham M. J.; Bajer M. G.; Long S. P. The potential of two perennial C4 grasses and a perennial C4 sedge as ligno-cellulosic fuel crop in N.W. Europe crop establishment and yields in E. England. Ann. Bot. 76: 520; 1995. doi:10.1006/anbo.1995.1127.

Reed C. List of insect species which may be tallgrass prairie specialists. University of Minnesota, St. Paul, MN; 1996.

Reeder J. R. Chromosome numbers in western grasses. Am. J. Bot. 64: 102-110; 1977. doi:10.2307/2441882.

Riedell W. E.; Gustin R. D.; Beck D. L. Effect of irrigation on rootgrowth and yield of plants damaged by western corn-rootworm larvae. Maydica 37: 143-148; 1992.

Russelle M. P.; Morey R. V.; Baker J. M.; Porter P. M.; Jung H.-J. Comment on "carbon-negative biofuels from low-input highdiversity grassland biomass". Science 316: 1567b; 2007. doi:10.1126/science. 1139388 .

Ryan, A. B. Agronomic and molecular characterization of Louisiana native Spartina alterniflora accessions. Agronomy. Dissertation, Louisiana State University and Agricultural and Mechanical College; 2003.

Sanderson M. A.; Adler P. R. Perennial forages as second generation bioenergy crops. Int. J. Mol. Sci. 9: 768-788; 2008. doi:10.3390/ ijms 9050768 . 
Sanderson M. A.; Adler P. R.; Boateng A. A.; Casler M. D.; Sarath G. Switchgrass as a biofuels feedstock in the USA. Can. J. Plant Sci. 86: 1315-1325; 2006.

Sanderson M. A.; Brink G. E.; Higgins K. F.; Naugle D. E. Alternative uses of warm-season forage grasses. In: Moser L. E.; Burson B. L.; Sollenberger L. E. (eds) Warm-season $\left(\mathrm{C}_{4}\right)$ grasses. Agronomy Monograph No. 45. ASA, CSSA, SSSA, Madison, WI, pp 389-416; 2004.

Sarath G.; Mitchell R. B.; Sattler S. E.; Funnell D.; Pedersen J. F.; Graybosch R. A.; Vogel K. P. Opportunities and roadblocks in utilizing forages and small grains for liquid fuels. J. Ind. Microbiol. Biotechnol. 35: 343-354; 2008. doi:10.1007/s10295-007-0296-3.

Schmer M. R.; Vogel K. P.; Mitchell R. B.; Perrin R. K. Net energy of cellulosic ethanol from switchgrass. Proc. Natl. Acad. Sci. U. S. A. 105: 464-469; 2008. doi:10.1073/pnas.0704767105.

Schnoor J. L. Biofuels and the environment. Environ. Sci. Tech. 40: 4042-4042; 2006. doi:10.1021/es0627141.

Searchinger T.; Heimlich R.; Houghton R. A.; Dong F. X.; Elobeid A.; Fabiosa J.; Tokgoz S.; Hayes D.; Yu T. H. Use of us croplands for biofuels increases greenhouse gases through emissions from land-use change. Science 319: 1238-1240; 2008. doi:10.1126/ science. 1151861.

Simpson T. W.; Sharpley A. N.; Howarth R. W.; Paerl H. W.; Mankin K. R. The new gold rush: Fueling ethanol production while protecting water quality. J. Environ. Qual. 37: 318-324; 2008. doi:10.2134/jeq2007.0599.

Sims P. L.; Risser P. G. Grasslands. In: Barbour M. G.; Billings W. D. (eds) North American terrestrial vegetation. Cambridge Univ. Press, Cambridge, MS, pp 323-356; 2000.

Sloop C. M.; McGray H. G.; Blum M. J.; Strong D. R. Characterization of 24 additional microsatellite loci in Spartina species (Poaceae). Conservat. Genet. 6: 1049-1052; 2005. doi:10.1007/ s10592-005-9084-7.

Smiley R. W.; Easley S. A.; Gourlie J. A. Annual spring wheat yields are suppressed by root-lesion nematodes in Oregon. Phytopathology 96: S171-S171; 2006. doi:10.1094/PHYTO-96-0171.

Smolik J. D. The role of nematodes in a South Dakota grassland ecosystem. Plant Science Department, South Dakota State University, Brookings, SD, p 74; 1973.

Somleva M. N.; Snell K. D.; Beaulieu J. J.; Peoples O. P.; Garrison B. R.; Patterson N. A. Production of polyhydroxybutyrate in switchgrass, a value-added co-product in an important lignocellulosic biomass crop. Plant Biotechnol. 6: 663-678; 2008. doi:10.1111/j.1467-7652.2008.00350.x.

Song K.; Lu P.; Tang K.; Osborn T. C. Rapid genome change in synthetic polyploids of Brassica and its implications for polyploid evolution. Proc. Natl. Acad. Sci. U. S. A. 92: 77197723; 1995. doi:10.1073/pnas.92.17.7719.

Songstad D. D.; Chen C. H.; Boe A. A. Plant regeneration in callus cultures derived from young inflorescences of little bluestem. Crop Sci. 26: 827-829; 1986.

Stewart D. A. B. Economic losses in cereal crops following damage by the African migratory locust, Locusta migratoria migratorioides (Reiche \& Fairmaire) (Orthoptera: Acrididae), in the northern province of South Africa. Afr. Entomol. 5: 167-170; 1997.

Stubbiendieck J.; Hatch S. L.; Kjar K. J. North American range plants. University of Nebraska Press, Lincoln, NE; 1982.

Tilman D.; Hill J.; Lehman C. Carbon-negative biofuels from lowinput high-diversity grassland biomass. Science 314: 1598-1600; 2006. doi:10.1126/science. 1133306.

Tober D. A.; Duckwitz W.; Knudson W. Big bluestem trials in North Dakota, South Dakota, and Minnesota. USDA NRCS Plant Materials Center, Bismark, ND; 2008.

Tobias C. M.; Hayden D. M.; Twigg P.; Sarath G. Genic microsatellite markers derived from EST sequences of switchgrass (Panicum virgatum L.). Mol. Ecol. Notes 6: 185-187; 2006. doi:10.1111/ j.1471-8286.2006.01187.x.

Tobias C. M.; Sarath G.; Twigg P.; Lindquist E.; Pangilinan J.; Penning B. J.; Barry K.; McCann M. C.; Carpita N. C.; Lazo G. R. Comparison of switchgrass ESTs with the Sorghum genome and development of EST-SSR markers. Plant Genome 2: 111124; 2008. doi:10.3835/plantgenome2008.08.0003.

Tobias C. M.; Twigg P.; Hayden D. M.; Vogel K. P.; Mitchell R. M.; Lazo G. R.; Chow E. K.; Sarath G. Analysis of expressed sequence tags and the identification of associated short tandem repeats in switchgrass. Theor. Appl. Genet 111: 956-964; 2005. doi:10.1007/s00122-005-0030-3.

Todd M. C.; Washington R.; Cheke R. A.; Kniveton D. Brown locust outbreaks and climate variability in southern Africa. J. Appl. Ecol. 39: 31-42; 2002. doi:10.1046/j.1365-2664.2002.00691.x.

Travis S. E.; Hester M. W. A space-for-time substitution reveals the longterm decline in genotypic diversity of a widespread salt marsh plant, Spartina alterniflora, over a span of 1500 years. J. Ecol. 93: 417430; 2005. doi:10.1111/j.0022-0477.2005.00985.x.

U.S. DOE. Breaking the biological barriers to cellulosic ethanol: A joint research agenda, DOE/SC-0095 U.S. Department of Energy Office of Science and Office of Energy and Renewable Energy (http://www.doegenomestolife.org/biofuels/); 2006.

USDA-NRCS. Summary report, 1997 National Resources Inventory. Revised Dec. 2000 - Table 4 (http://www.nrcs.usda.gov/technical/ NRI/1997/summary_reports/table4.html; website verified 5 Feb. 2009); 2000.

USDA-SCS. Land resource regions and major land resource areas of the United States. In: USDA-SCS (ed) Superintendent of documents. U.S. Government Print Office, Washington, DC; 1981.

Varvel G. E.; Vogel K. P.; Mitchell R. B.; Follett R. F.; Kimble J. M. Comparison of corn and switchgrass on marginal soils for bioenergy. Biomass Bioenergy 32: 18-21; 2008. doi:10.1016/j. biombioe.2007.07.003.

Vogel K. P.; Brejda J. J.; Walters D. T.; Buxton D. R. Switchgrass biomass production in the Midwest USA: Harvest and nitrogen management. Agron. J. 94: 413-420; 2002.

Vogel K. P.; Jung H. G. Genetic modification of herbaceous plants for feed and fuel. Crit. Rev. Plant Sci. 20: 15-49; 2001. doi:10.1016/ S0735-2689(01)80011-3.

Weaver J. E. Extent of communities and abundance of the most common grasses in prairie. Bot. Gaz. 122: 25-33; 1960. doi:10.1086/336082.

Weaver J. E. North American prairie. Johnsen, Lincoln, NE; 1954.

Weaver J. E.; Fitzpatrick T. J. Ecology and relative importance of the dominants of the tall-grass prairie. Bot. Gaz. 93: 113-150; 1932. doi: $10.1086 / 334244$.

Wells G. R.; Fribourg H. A.; Schlarbaum S. E.; Ammons J. T.; Hodges D. G. Alternate land uses for marginal soils. J. Soil Water Conserv. 58: 73-81; 2003.

Willis W. O.; Bauer A.; Black A. L. Water conservation: Northern great plains. In: Dregne H. E.; Willis W. O. (eds) Dryland agriculture. Agronomy Monograph 23. ASA, CSSA, SSSA, Madison, WI; 1983.

Wipff J. K. Nomenclature combinations of Schizachyrium (Poaceae: Andropogoneae). Phytologia 80: 35-39; 1996.

Wu R.; Gallo-Meagher M.; Littell R. C.; Zeng Z. A general polyploid model for analyzing gene segregation in outcrossing tetraploid species. Genetics 159: 869-882; 2001.

Wu R.; Ma C. A general framework for statistical linkage analysis in multivalent tetraploids. Genetics 170: 899-907; 2005. doi:10.1534/genetics.104.035816.

Young D. K. Remnant dependence among prairie-inhabiting and savanna-inhabiting insects. Nat. Area J. 15: 290-292; 1995.

Young Sa; Park S. K.; Rodgers C.; Mitchell R. E.; Bender C. L. Physical and functional-characterization of the gene-cluster encoding the polyketide phytotoxin coronatine in Pseudomonas-syringae $p v$ glycinea. J. Bacteriol. Virol. 174: 1837-1843; 1992. 